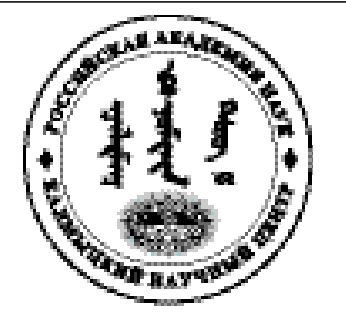

Published in the Russian Federation

Oriental Studies (Previous Name: Bulletin of the Kalmyk Institute

for Humanities of the Russian Academy of Sciences)

Has been issued as a journal since 2008

ISSN: 2619-0990; E-ISSN: 2619-1008

Vol. 13, Is. 4, pp. 866-875, 2020

DOI: $10.22162 / 2619-0990-2020-50-4-866-875$

Journal homepage: https://kigiran.elpub.ru

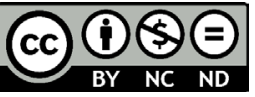

УДК 94 (517)

DOI: $10.22162 / 2619-0990-2020-50-4-866-875$

\title{
Дальневосточная республика как «колыбель» Монгольской революции (к 100-летию ДВР и Монгольской революции 1921 г.)
}

\section{Леонид Владимирович Курас ${ }^{1}$, Базар Догсонович Цьбенов}

${ }^{1}$ Институт монголоведения, буддологии и тибетологии Сибирского отделения РАН (д. 6, ул. Сахьяновой, 670047 Улан-Удэ, Российская Федерация) доктор исторических наук, главный научный сотрудник (iD) 0000-0003-4507-249X. E-mail: kuraslv@yandex.ru

${ }^{2}$ Институт монголоведения, буддологии и тибетологии Сибирского отделения РАН (д. 6, ул. Сахьяновой, 670047 Улан-Удэ, Российская Федерация) кандидат исторических наук, старший научный сотрудник iD 0000-0002-0404-7207. E-mail: bazar75@mail.ru

(C) КалмНЦ РАН, 2020

(C) Курас Л. В., Цыбенов Б. Д., 2020

Аннотация. Введение. Дальневосточная республика, появившаяся в качестве «буферного» государства весной 1920 г., сыграла важную роль в транснациональной истории монгольского мира. Монгольские революционеры, осознавая потенциальные возможности большевистской власти и необходимость использования в своих целях российско-монгольского приграничья, решились на установление прямых контактов с региональными властями Дальневосточной республики и РСФСР. Целью исследования явилось изучение организационной роли Дальневосточной республики в качестве форпоста Монгольской революции 1921 г. Для ее решения были поставлены следующие задачи: изучение российско-монгольского революционного взаимодействия в 1918-1920 гг.; освещение деятельности уполномоченного Народного комиссариата иностранных дел РСФСР в Монголии О. И. Макстенека; рассмотрение маршрута и работы трех групп монгольских делегатов в пределах Дальневосточной республики и Советской России в 1920 г.; созыв первого съезда Монгольской народной партии в марте 1920 г. в г. Троицкосавске. Материалами исследования послужили архивные документы по истории российско-монгольского военного сотрудничества в первой половине XX в., работы отечественных и монгольских авторов по исследуемой проблематике. Результаты. Выяснено, что подготовительные мероприятия Монгольской революции 1921 г., включая основополагающие поездки и собрания монгольских революционеров во второй половине 1920 - начале 1921 гг., проходили на территории буферного государства - Дальневосточной республики. Bblвoдbl: Руководство Дальневосточной республики во главе с Б. 3. Шумяцким и уполномоченный Народного ко- 
миссариата иностранных дел РСФСР в Монголии О. И. Макстенек сыграли большую роль в организации деятельности монгольских делегатов-революционеров и в целом в укреплении у них мысли о суверенной Монголии с опорой на советскую власть и ее вооруженные силы.

Ключевые слова: Советская Россия, Дальневосточная республика, монгольские революционеры, «буферное» государство, О. И. Макстенек, российско-монгольское революционное взаимодействие

Благодарность. Исследование проведено в рамках проекта РФФИ - Министерства образования, культуры и науки (Монголия) № 19-59-44004 «Монгольская революция 1921 г. в зеркале транснациональной истории монгольского мира» (к 100-летию Монгольской революции 1921 г.) (регистрационный номер АААА-А20-120021490062-5). Материалы статьи апробированы на Международной научной онлайн-конференции «Монголоведение в начале XXI в.: современное состояние и перспективы развития-II», проведенной при финансовой поддержке РФФИ (проект № 20-09-22004) и частичной поддержке гранта Правительства РФ (№ 075-152019-1879).

Для цитирования: Курас Л. В., Цыбенов Б. Д. Дальневосточная республика как «колыбель» Монгольской революции (К 100-летию ДВР и Монгольской революции 1921 г.) // Oriental studies. 2020. T. 13. № 4. С. 866-875. DOI: 10.22162/2619-0990-2020-50-4-866-875

UDC 94 (517)

DOI: $10.22162 / 2619-0990-2020-50-4-866-875$

\title{
Far Eastern Republic as a 'Cradle' of the Mongolian Revolution: Celebrating the $\mathbf{1 0 0}^{\text {th }}$ Anniversaries of the Far Eastern Republic and the Mongolian Revolution of 1921
}

\author{
Leonid V. Kuras ${ }^{1}$, Bazar D. Tsybenov ${ }^{2}$
}

${ }^{1}$ Institute for Mongolian, Buddhist and Tibetan Studies, Siberian Branch of the RAS (6, Sakhyanova St., Ulan-Ude 670047, Russian Federation)

Dr. Sc. (History), Chief Research Associate

iD 0000-0003-4507-249X. E-mail: kuraslv@yandex.ru

${ }^{2}$ Institute for Mongolian, Buddhist and Tibetan Studies, Siberian Branch of the RAS (6, Sakhyanova St., Ulan-Ude 670047, Russian Federation)

Cand. Sc. (History), Senior Research Associate

iD 0000-0002-0404-7207.E-mail: bazar75@mail.ru

(C) KalmSC RAS, 2020

(C) Kuras L. V., Tsybenov B. D., 2020

\begin{abstract}
Introduction. The Far Eastern Republic that emerged in the spring of 1920 suited all political players - Moscow, Tokyo, Washington, Irkutsk Political Center, and other peripheral political forces of the Far East. The 'buffer' state also played an important role in the transnational history of the Mongolian world. Mongolian revolutionaries stayed in the territory of the Far Eastern Republic in the summer and autumn of 1920. At that time, they were deeply imbued with the ideas of the Bolsheviks. Goals. The study seeks to examine the organizational role of the Far Eastern Republic as an outpost of the Mongolian Revolution of 1921. The objectives be tackled are as follows: investigation of the Russian-Mongolian revolutionary interaction in 1918-1920; analysis of activities of O. Maksteneck, an authorized representative of the RSFSR People's Commissariat for Foreign Affairs to Mongolia; exploration of the route and work of three groups of Mongolian delegates in the territory of the Far Eastern Republic and Soviet Russia in 1920; insight into activities of the first congress of the Mongolian People's Party in Troitskosavsk in March 1920. Materials. The paper analyzes archival documents dealing with the history of Russian-Mongolian military cooperation in the early-to-mid
\end{abstract}


$20^{\text {th }}$ century, considers works by domestic and Mongolian authors dedicated to the creation of the Far Eastern Republic and the Mongolian Revolution of 1921. Conclusions. The leadership of the Far Eastern Republic headed by B. Shumyatsky and the authorized representative of the RSFSR People's Commissariat for Foreign Affairs O. Maksteneck played a crucial role in organizing the activities of the Mongolian revolutionary delegates. They convinced the Mongolian revolutionaries of the need to rely on Soviet power and its armed forces in the struggle for Mongolian independence.

Keywords: Soviet Russia, Far Eastern Republic, Mongolian revolutionaries, 'buffer' state, O. Maksteneck, Russian-Mongolian revolutionary interaction

Acknowledgements. The reported study was funded by RFBR and Ministry of Education, Culture and Science of Mongolia, no. 19-59-44004 'The Mongolian Revolution of 1921 in the Mirror of Transnational History of the Mongolian World: Celebrating the $100^{\text {th }}$ Anniversary of the Mongolian Revolution of 1921' (state reg. no. AAAA-A20-120021490062-5). The article was presented at the International scientific online conference 'Mongolian Studies at the Beginning of the $21^{\text {st }}$ Century: Current State and Development Prospects - II' funded by RFBR (project no. 20-09-22004) and Government of Russia (grant no. 075-15-2019-1879).

For citation: Kuras L. V., Tsybenov B. D. Far Eastern Republic as a 'Cradle' of the Mongolian Revolution: Celebrating the $100^{\text {th }}$ Anniversaries of the Far Eastern Republic and the Mongolian Revolution of 1921. Oriental Studies. 2020. Vol. 13(4): 866-875. (In Russ.). DOI: 10.22162/26190990-2020-50-4-866-875

\section{Введение}

Мы уже рассматривали предпосылки Монгольский революции 1921 г. как продолжение «революции в колчакии» [Курас 2017; Курас, Хишигт, Цыбенов 2020]. При этом наше внимание было сконцентрировано на том факте, что эта связь позволяет современной историографии взглянуть на события в Центральной Азии через призму «транснациональной истории монгольского мира» [Курас 2016б].

В центре внимания такого направления стоит «изучение закономерностей, общих для всех национальных культур, а также взаимосвязей, конфликтов, войн, революций, которые невозможно объяснить как результат действий отдельного государства. Поэтому именно транснациональная история позволяет по-новому рассмотреть феномен революции» [Курас 2016а: 84].

В свою очередь такая «перспектива позволяет не только осветить трансграничные аспекты развития национальных движений в Сибири и Монголии, приведших среди прочего к созданию и частичной реализации национальных проектов, но и реконструировать историю национализма как глобального дискурса, оказавшего в $\mathrm{XX}$ в. значительное влияние на властные отношения и постимперское переустройство во всех регионах мира» [Саблин 2014:
135-136]. И в русле этой идеи особая роль принадлежит Дальневосточной республике (ДВР).

Непредсказуемость эпохи кардинальных перемен: корреляция феномена Дальневосточной республики и Монгольской революции 1921 г.

Кратко о феномене Дальневосточной республики

Для современной российской историографии особую важность представляет феномен республики, который никогда не рассматривался как марионеточное государство. И в этом плане феномен Дальневосточной Республики навсегда запечатлен в истории как новое государственное образование, которое появилось в «нужное время и в нужном месте». Она удивительным образом устраивала всех политических игроков: Москву, Токио, Вашингтон, Иркутский Политцентр и другие периферийные политические силы Дальнего Востока.

Это было абсолютно взвешенное и единственно правильное решение, так как территория от Байкала и до Владивостока была плотно насыщена японскими войсками, а сама Советская Россия была на пороге войны с Польшей.

Для современной науки и политических технологий - это был уникальный случай, когда имела место конкуренция различных 
взглядов на будущее региона в конкретный период. Так, национальные сценарии, связывали это будущее с интересами одной из групп местного населения: русских, бурят-монголов, корейцев, украинцев и других [Саблин 2020: 25; 52-54; 83-89; 141-152].

В рамках транснациональных проектов имели место попытки интегрировать Дальний Восток в политические и экономические зоны влияния Японии и США. Большевики и Коминтерн рассматривали регион как плацдарм для экспорта революции в Монголию, Корею, Китай и Японию. Так, в условиях начавшегося соперничества с США за влияние на русский Дальний Восток, наличие «буфера» оказалось необходимым для Японии, которая полагала возможным иметь здесь преобладающее влияние.

Северо-Американские Соединенные Штаты были убеждены, что американская экономика позволит им стать единоличными хозяевами в регионе. Для Иркутского Политцентра «буфер» был нужен для остановки наступления «красных», а на переговорах с большевиками выдвигались доводы прямо противоположные. Но при этом никто из политических игроков даже в мыслях не держал Монголию, которая, как показала последующая история, получила от существования «буфера» не меньше, а может быть и больше, нежели Советская Россия.

6 апреля 1920 г. начал работу съезд трудящихся Западного Забайкалья в Верхнеудинске, в котором приняли участие представители всех политических партий и земств. В соответствии с планом Сиббюро ЦК РКП (б) съезд провозгласил создание Дальневосточной республики со столицей в г. Верхнеудинске. Съезд направил правительствам и народам мирового сообщества декларацию о создании нового, независимого и демократического государства - Дальневосточной республики. Тем самым была создана буферная зона между Российской Советской Федеративной Социалистической Республикой (РСФСР) и Японией. В новом государстве были приняты все атрибуты государственности: государственный герб, государственный флаг и национальная валюта (рубль Дальневосточной республики).

14 мая 1920 г. советское правительство официально признало Дальневосточную республику и объявило о готовности обменяться верительными грамотами.

В середине сентября 1920 г. японцы приняли решение о выводе войск из Забайкалья, что нанесло сокрушительный удар по позициям Г. М. Семёнова. В середине октября 1920 г. был завершен вывод японских войск из Забайкалья. А «с 28 октября по 10 ноября 1920 г. в Чите состоялась конференция областных правительств Дальнего Востока. На ней была приняла декларация, провозглашавшая объединение всей территории «бывшей Российской империи к Востоку от Селенги и озера Байкала до Тихого Океана, включая области Западно-Забайкальскую, Восточно-Забайкальскую, Амурскую, Приморскую, Сахалин и Камчатку» [Саблин 2020: 147] в единую независимую республику.

Тем самым текст, предложенный идеологом и видным функционером ДВР А. М. Краснощёковым, начал отсчет истории республики с 6 апреля 1920 г., т. е. с того дня, когда была подписана декларация независимости в Верхнеудинске, что фактически означало признание ведущей роли верхнеудинского правительства [Саблин 2020: 147].

В тоже время по воспоминаниям Виктора Кина, одного из участников большевистского подполья на Дальнем Востоке: «Это была веселая республика - ДВР! В парламенте бушевали фракции, что-то вносили, согласовывали... Над председателем висел герб, почти советский, но вместо серпа и молота были кайло и якорь. Флаг был красный, но с синим квадратом в углу. Армия носила пятиконечные звезды - но, наполовину синие, наполовину красные. И вся республика была такой же, половинной» [Григорьев 2017].

Тем не менее ДВР оставила глубокий след в истории и памяти русского Дальнего Востока, ибо Дальневосточная республика - это уникальный опыт строительства «буфера» с целью недопущения большой войны с Японией и одна из первых попыток в мировой истории совмещения революционной диктатуры пролетариата и крестьянства с буржуазными институтами. Кроме того, это заключительный аккорд кровопролитной гражданской войны в России. 


\section{Монгольские революционеры в 1920 2.: от замыслов к реализации планов}

События 1920 г. являются значимыми не только для истории Советской России, но и для сопредельных территорий. В истории Монголии этот год (1920) также стал ключевым. В июне 1920 г. две подпольные антикитайские группы «Консульский холм» (Д. Бодоо и Х. Чойбалсан) и «Восточное хурэ» (С. Данзан, Д. Догсом, Д. Сухэ-Батор) объединились в Монгольскую народную партию (МНП). Они прекрасно понимали, что, рассчитывая только на собственные силы, они не добьются желанной независимости Монголии. И потому монгольские революционеры решили обратить свои взоры на Советскую Россию.

Советская Россия стремилась установить дружественные связи с Монголией, руководствуясь не только общностью границы. Этот интерес имел глубокие корни:

1) советское руководство ясно понимало стратегическую роль Монголии в своем стремлении выйти за пределы собственных рубежей, к осуществлению мировой революции;

2) для реализации идеи мировой революции и поворота ее вектора на восток, Монголия рассматривалась РКП (б) и Коминтерном как реальный плацдарм будущей революции в Азии;

3) интерес к Монголии имел и экономическую составляющую: Советская Россия надеялась восстановить невосполнимые потери, понесенные в годы революции и братоубийственной войны, за счет монгольских ресурсов.

РКП (б) и Коминтерн были прекрасно информированы об успехах и недостатках подпольной деятельности монгольских революционеров. Директивные органы Советской России и ДВР всячески содействовали монголам в их борьбе с китайскими милитаристами, а в более широком смысле - в осуществлении национальной революции.

Весной 1918 г. РСФСР направило правительству Монголии официальное уведомление о том, что она аннулирует все прежние царские договоры и предлагает установить со своим монгольским соседом устойчивые связи. В августе 1919 г. правительство РСФСР выступило с новым обращением к монгольскому правительству и монгольскому народу, в котором признало право мон- гольского народа самостоятельно устраивать государственную жизнь и предложило установить дипломатические отношения.

В марте 1920 г. в Ургу прибыл функционер Сиббюро ЦК РКП (б) Н. Г. Буртман, который разъяснил монгольским революционерам основные положения программы партии большевиков, ее стратегию и тактику [Базаров, Жабаева 2008: 181]. А в мае 1920 г. в Ургу прибыли советские представители, возглавляемые сотрудником Сибирского бюро РКП (б) С. С. Борисовым, в последующем заведующим «монголо-тибетским отделом секции восточных народов Сиббюро РКП (б)» [Рощин 1999: 29]. Именно тогда у монгольских революционеров возникает мысль о том, чтобы сделать ставку на Советскую Россию.

Для решения поставленных задач Учредительное собрание МНП 25 июня 1920 г. постановило: направить в РСФСР тремя группами делегацию сначала С. Данзана и Х. Чойбалсана, следом - Д. Бодоо и Д. Чагдаржава и за ними - Д. Сухэ-Батора, Д. Догсома и Д. Лосола.

Троицкосавск, О. И. Макстенек и монгольские делегации: укрепление революционного взаимодействия

В июне 1920 г. к своим обязанностям приступил уполномоченный Наркомата иностранных дел РСФСР в Монголии Отто Иванович Макстенек [Курас, Цыбенов 2020]. Китайские оккупационные власти в Урге не пропустили его через границу, и О. И. Макстенек остановился в ДВР, в пограничном городе Троицкосавск, где и открыл консульский отдел Советской России. Кроме своих непосредственных обязанностей советского дипломата, он занялся и иными делами, где ему пригодились навыки периода революционного подполья. Он установил тесные связи с монгольскими революционными кругами, осуществляя организационную, идеологическую и политическую работу на монгольском направлении. Кроме того, О. И. Макстенек осуществлял и посреднические функции, налаживая связи монгольских революционеров с представителями ДВР, Советской России и Коминтерна.

Первостепенной задачей О. И. Макстенека стала организационная работа. Именно он встречал, размещал, организовывал быт, обеспечивал охрану и поставлял необходи- 
мую информацию первой группы монгольских революционеров в лице С. Данзана и X. Чойбалсана, которые прибыли к нему в середине 1920 г. с рекомендацией члена Информбюро граждан Советской России в Монголии М. И. Кучеренко [Хишигт, Курас, Цыбенов 2020: 310]. Тем самым советский дипломат стал первым официальным лицом, принявшим монгольских революционеров. Поэтому вполне естественно, что именно он первым ознакомился с «Обращением делегации представителей монгольского народа и МНП к уполномоченному НКИД РСФСР в Троицкосавске О. И. Макстенеку с просьбой начать переговоры с правительством Советской России об оказании помощи Монголии в ее борьбе за освобождение» [РМВС 2008а: 106-107].

Важность этой встречи и особая роль ДВР были фактически сразу же озвучены уполномоченным НКИД РСФСР. Прежде всего, он извинился за то, что, имея дипломатический статус уполномоченного НКИД РСФСР, тем не менее принимает делегацию неофициально ввиду нелегального положения Монгольской народной партии и особенно «при теперешних обстоятельствах международной политики» [РМВС 2008б: 208].

Тем самым Уполномоченный НКИД О. И. Макстенек дал понять, что международное положение РСФСР таково, что она не может открыто контактировать с представителями нелегальной монгольской партии, чтобы не вызвать негативную реакцию со стороны Китая, США и Японии. И в этой связи ДВР приобретала положение не только «буфера», но и своеобразного форпоста будущей монгольской революции. И в этой связи О. И. Макстенеку отводилась особая роль: уполномоченный Наркомата иностранных дел РСФСР был не только осведомлен о делах монголов, но и знал о цели приезда делегации. Он же должен был отправить их в столицу ДВР - Верхнеудинск, отрабатывал маршрут передвижения, готовил адреса будущих встреч, постоянно находясь в прямой связи с председателем Совмина ДВР Б. З. Шумяцким [Хишигт 2017: 17].

Вторая группа монгольских революционеров - Д. Бодоо и Д. Чагдаржав - прибыла в Троицкосавск в начале августа. Их сопровождали С. С. Борисов и Ц.-И. Да- шепылов [Хишигт 2011: 155]. При встрече с уполномоченным НКИД Д. Бодоо и Ч. Чагдаржав передали ему «Обращение от представителей монгольского народа и Народно-революционной партии Внешней Монголии». В официальном документе выражалась уверенность в том, что Уполнаркоминдел окажет всяческое содействие в осуществлении их высокой миссии.

Третья группа монгольских делегатов Д. Сухэ-Батор, Д. Догсом и Д. Лосол прибыла в Троицкосавск 8 августа 1920 г. Делегацию встречали О. И. Макстенек и представитель Дальневосточного секретариата Исполнительного комитета Коммунистического интернационала И. А. Сороковиков. Им было передано «Письмо князей и лам Внешней Монголии». Именно с этим документом монгольские революционеры прибыли в Иркутск. Здесь они обратилась к Сибмиссии ЦК партии большевиков и Совнаркому.

Тем самым в течение полутора месяцев Дальневосточная республика и ее пограничный форпост Троицкосавск и квартира Отто Ивановича стали фактически «конспиративной квартирой» всех трех групп монгольских делегатов, на которой Уполномоченный НКИД РСФСР О. И. Макстенек встречался с ними ежедневно. Именно он организовал встречу монгольских революционеров с руководством ДВР. Тем самым Дальневосточная республика, «буфер», который устраивал всех, становится участницей большой политической игры. Именно здесь решается судьба будущей национальной революции. Именно здесь закладываются основы суверенной Монголии. Следует подчеркнуть, что опыт нелегальной работы монгольских партийцев сослужил им хорошую службу. Осенью 1920 г. Д. СухэБатор и Х. Чойбалсан длительное время после возвращения из Москвы находились на полулегальном положении на территории Джидинской долины (Джидинский район Республики Бурятия), а зимой 1921 г. скрывались в Гэгэтуйском и Дырестуйском дацанах. Они выезжали в Желтуру и другие пограничные населенные пункты для встречи с соратниками, занимались формированием партизанских отрядов. Все это время для оперативной информации о положении дел в Монголии в Троицкосавске оставался Д. Лосол. В конце февраля 1921 г. монголь- 
ские революционеры перебрались в Троицкосавск (Кяхту) [Мельников 2011].

Знакомство монгольских делегатов с руководителем ДВР Б. З. Шумяцким как пролог к новым встречам на высшем уровне в Советской России

В августе 1920 г. в г. Верхнеудинске состоялась встреча монгольской делегации с видным сибирским большевиком, стоявшим у истоков создания ДВР, идеологом будущей монгольской революции Б. 3. Шумяцким.

Монгольской делегации пришлось больше месяца находиться в столице ДВР Верхнеудинске [Хишигт 2017: 18]. Причины кажущейся нерасторопности Б. З. Шумяцкого и О. И. Макстенека объяснялись как международной обстановкой, так и политическим статусом ДВР:

1) Сиббюро ЦК РКП (б) ожидало объективную информацию от своих эмиссаров, уехавших в Ургу для ознакомления с постановкой революционной работы и реальным состоянием Народно-революционной партии;

2) советская сторона стремилась ознакомить руководителей революционной партии Монголии с накопленным большевиками опытом и методами партийно-политической работы;

3) будучи крупным партийным функционером, тем не менее председатель правительства ДВР Б. З. Шумяцкий не имел достаточных полномочий и ждал соответствующих инструкций от руководства РКП (б) и Совнаркома РСФСР [Хишигт 2017: 18].

Тем не менее встреча с руководителем ДВР Б. 3. Шумяцким в первой столице нового демократического государства имела огромное значение и для монгольских делегатов, и для «буферного» государства. Так, руководитель ДВР стал официальным экспертом статуса МНП и тем самым окончательно определил позицию «буфера», а значит и позицию РСФСР в отношении к Монголии. Кроме того, ДВР и его столица, уездный город Верхнеудинск, стали своеобразным центром революционной демократии, экспериментальной площадкой невиданного ранее опыта, проводимого большевиками, а также субъектом международной политики.

В то же время руководство Советской России и РКП (б), только что выйдя из опу- стошительной гражданской войны, старалось соблюдать нормы международного права. Именно по этой причине большевики не вмешивались во внутриполитическую борьбу в Монголии. К тому же они полагали, что революционный процесс в Монголии является сегментом аналогичного процесса в Китае, не принимая во внимание итоги Синьхайской революции и Кяхтинское соглашение 1915 г. Кроме того, цивилизованное общество имело свои устоявшиеся дипломатические традиции, и Советская Россия старалась следовать им неукоснительно. В этой связи РСФСР должна была на официальном уровне проводить более взвешенную и сдержанную политику. Все это делало положение монгольских революционеров довольно двусмысленным. Тем не менее в руководстве Дальневосточной республики с подачи РКП (б) и Коминтерна предпринимают ряд шагов, необходимых для урегулирования отношений между двумя странами.

Последующие события и пребывание монгольской делегации в Иркутске, а затем в Москве, где состоялась встреча с руководством Советской России во главе с В. И. Лениным, получили широкое освещение и высокую оценку в российской и монгольской историографии [История Монголии 2008].

Обзор событий в Монголии и сопредельных регионах в конце 1920 - начале 1921 z2.

2 ноября 1920 г. барон Р. Ф. Унгерн во главе «Азиатской конной дивизии» нарушил границу Монголии, создав серьезную опасность для монгольской государственности. 10 и 27 ноября Нарком иностранных дел РСФСР Г. В. Чичерин направил республиканскому Китаю две ноты, в которых предложил организовать совместные действия против мятежного барона. Но центральное китайское правительство проигнорировало предложения дипломатического ведомства РСФСР. Не имея согласия Пекина, а также учитывая существовавшую угрозу со стороны Японии, советское руководство в 1920 г. не отважилось ввести свои войска в Монголию. Этой ситуацией воспользовался барон. 4 февраля 1921 г. он с помощью монгольских войск освободил Ургу и изгнал китайских 
оккупантов. Победа Р. Ф. Унгерна над китайцами во многом была обеспечена монгольскими войсками, мобилизованными по указу Богдо-хана. Тем самым была восстановлена монгольская государственность в форме автономии, но фактическая власть в Монголии оказалась в руках «освободителя» барона Р. Ф. Унгерна. Вокруг него стали концентрироваться разрозненные белогвардейские отряды, оказавшиеся в Монголии под напором наступавших частей 5-й Армии. Одновременно с этим на территории Монголии концентрировались и китайские вооруженные формирования. Сложившаяся политическая и военная ситуация в Монголии вызвали серьезную обеспокоенность не только у руководства МНП, но и руководства РСФСР. Оставшиеся в Иркутске монгольские революционеры, 2 ноября 1920 г. обратились в Секцию восточных народов и через нее к советскому правительству. 17 ноября 1920 г. в Иркутске состоялось совместное совещание советских и монгольских партийных работников, которое стало отправной точкой принятия решения о вооруженной борьбе против китайских войск в Монголии, за независимость и суверенитет монгольского государства. Перед революционерами были поставлен ряд задач: осуществить разведку расположения китайских войск и белогвардейских отрядов, вести постоянную пропаганду среди монгольского населения о необходимости борьбы против иноземных захватчиков, проводить конкретные мероприятия, направленные на развитие национально-освободительного движения и создание народно-революционной армии [Бат-Очир, Дашжамц 1973: 117].

\section{Источники}

РМВС 2008а - Российско-монгольское военное сотрудничество (1911-1946). Сб. док.: в 2 ч. / отв. ред. В. П. Козлов, Д. Улзий-баатар. Ч. І. М. Улан-Удэ: Изд-во ВСГАКИ, 2008. 349 с. РМВС $2008 б$ - Российско-монгольское военное сотрудничество (1911-1946). Сб. док.: в 2 ч. /отв. ред. В. П. Козлов, Д. Улзий-баатар. Ч. II. М. Улан-Удэ: Издво ВСГАКИ, 2008. 326 с.
Все это время для оперативной информации о положении дел в Монголии в Троицкосавске оставался Д. Лосол, куда в конце февраля 1921 г. перебрались и другие монгольские революционеры.

\section{Вместо заключения}

В начале марта Троицкосавск (Кяхта) и консульство НКИД РСФСР (квартира О. И. Макстенека) стали местом важнейшего события в истории Монголии XX в. Здесь, 1-3 марта 1921 г. состоялось учредительное собрание, а фактически первый съезд Монгольской народной партии (с 1925 г. - Монгольская народно-революционная партия, МНРП). Съезд избрал ЦК партии и выработал политическую платформу, где были поставлены следующие задачи предстоящей революции:

- уничтожение империалистического гнёта;

- достижение национальной независимости;

- торжество народной власти;

- демократизация общественной жизни страны.

Вскоре МНП была принята в Коминтерн в качестве сочувствующей партии. Тогда же в Кяхте начали формироваться первые четыре полка. Это стало фундаментом будущей Монгольской народно-революционной армии. Приближалось лето 1921 г., а вместе с ним и победоносная Монгольская народная революция.

Таким образом, среди множества версий развития российского Дальнего Востока вверх одержал большевистский сценарий, а Дальневосточная республика превратилась в «колыбель» будущей Монгольской революции.

\footnotetext{
Sources

Kozlov V. P., D. Ölziibaatar (eds.) Russian-Mongolian Military Cooperation: 1911-1946. Collected Documents. In 2 vols. Vol. I. Ulan-Ude: East Siberian State Institute of Culture, 2008. 349 p. (In Russ.)

Kozlov V. P., D. Ölziibaatar (eds.) Russian-Mongolian Military Cooperation: 1911-1946. Collected Documents. In 2 vols. Vol. II. Ulan-Ude: East Siberian State Institute of Culture, 2008. 326 p. (In Russ.)
} 


\section{Литература}

Базаров, Жабаева 2008 - Базаров Б. В., Жабаева Л. Б. Бурятские национальные демократы и общественно-политическая мысль монгольских народов в первой трети XX века. Улан-Удэ: Изд-во БНЦ СО РАН, 2008. $377 \mathrm{c}$.

Бат-Очир, Дашжамц 1973 - Бат-Очир Л., Дачжами Д. Дамдингийн Сүхбаатар. Намтар (Дамдины Сухэ-Батор. Биография). Улаанбаатар: Улсын хэвлэлийн газар, 1973. 156 х.

Григорьев 2017 - Григорьев Евгений. Дальневосточная республика. История одного буферного образования [электронный ресурс] // Живая история. 1 июня 2017 г. URL: http:// lhistory.ru/statyi/dalnevostochnaya-respublika (дата обращения: 10.03.2020).

История Монголии 2008 - История Монголии. ХХ век / отв. ред. Г. С. Яскина. М.: ИВ РАН, 2008. $448 \mathrm{c}$.

Курас 2017 - Курас Л. В. «Революция в колчакии» и предпосылки Монгольской революции 1921 года // Иркутский историко-экономический ежегодник: 2017. Иркутск: Изд-во БГУ, 2017. С. 76-81.

Курас 2016а - Курас Л. В. Бурятская национальная автономия 1917 года в транснациональной истории // Иркутский историко-экономический ежегодник. 2016. Иркутск: Изд-во БГУ, 2016. С. 84-92.

Курас $2016 б$ - Курас Л. В. Транснациональная история монгольского мира в условиях революционного подъема: первая четверть XX в. Иркутск: Оттиск, 2016. 252 с.

Курас, Хишигт, Цыбенов $2020-$ Курас Л. В., Хишигт Н., Цыбенов Б. Д. От «революции в колчакии» до Монгольской революции 1921 года // Иркутский историко-экономический ежегодник: 2020. Иркутск: Изд-во БГУ, 2020. С. 385-392.

Курас, Цыбенов 2020 - Курас Л. В., Цыбенов

\section{References}

Bat-Ochir L., Dashjamts D. Damdin Sükhbaatar: Biography. Ulaanbaatar: People's Publ. House, 1973. 156 p. (In Mong.)

Bazarov B. V., Zhabaeva L. B. Buryat National Democrats and Sociopolitical Thought of Mongolic Peoples: 1900s-1930s. Ulan-Ude: Buryat Scientific Center (Siberian Branch of RAS), 2008. 377 p. (In Russ.)

Grigoriev E. Far Eastern Republic: a history of one buffer state. On: Zhivaya Istoriya (journal website). Posted on June 1, 2017. Available
Б. Д. Отто Иванович Макстенек: год из жизни советского дипломата // Известия Иркутского государственного университета. Серия «История». 2020. Т. 32. С. 83-90.

Мельников 2011 - Мельников И. Д. Гражданская война в Джиде. 1918-1921 гг. Сборник статей, воспоминаний и биографических сведений участников граждан. Улан-Удэ: [б. и.], 2011. 399 с.

Саблин 2014 - Саблин И. В. «Вильсоновский момент» на Восточном фронте: война, национализм и буддизм в Сибири и Монголии // Первая мировая война в «восточном измерении». Сб. науч. ст. М.: ИВ РАН, 2014. C. $135-136$.

Саблин 2020 - Саблин И. В. Дальневосточная республика. От идеи до ликвидации. М.: НЛО, 2020. $260 \mathrm{c}$.

Рощин 1999 - Рощин С. К. Политическая история Монголии (1921-1940 гг.). М.: ИВ РАН, 1999.325 c.

Хишигт 2017 - Хишигт Н. Великая Российская революция 1917 г. и национально-освободительное движение монголов // Сибирь в годы Великой Российской революции. Матлы Всерос. науч.-практ. конф. с междунар. участием (к 100-летию революционных событий в России и периоду Гражданской войны интервенции). Улан-Удэ: Изд-во ВСГУТУ, 2017. С. 14-23.

Хишигт 2011 - Хишигт Н. Восстановление независимости Монголии в 1911-1921 гг. // Вестник Бурятского научного центра Сибирского отделения Российской академии наук. 2011. № 3. С. 19-35.

Хишигт, Курас, Цыбенов $2020-$ Хишигт H., Курас Л. В., Цыббенов Б. Д. Отто Иванович Макстенек: у истоков монгольской революции 1921 года // Oriental studies. 2020. Т. 13. № 2 C. 305-317. DOI: $10.22162 / 2619-0990-$ 2020-48-2-305-31

at: http://history.ru/statyi/dalnevostochnayarespublika (accessed: March 10, 2020). (In Russ.)

Khishigt N. The impact of the Russian Revolution of 1917 on the national liberation movement in Mongolia. In: Zhabaeva L. B., Kuras L. V. et al. (eds.) Siberia in the Years of the Russian Revolution. Conference Proceedings. Ulan-Ude: East Siberia State University of Technology and Management, 2017. Pp. 14-23. (In Russ.)

Khishigt N. The restoration of Mongolian independence in 1911-1921. Bulletin of the 
Buryat Scientific Center of the Siberian Branch of the Russian Academy of Sciences. 2011. No. 3. Pp. 19-35. (In Russ.)

Khishigt N., Kuras L. V., Tsybenov B. D. Otto I. Makstenek: at the origins of the Mongolian Revolution of 1921. Oriental Studies. 2020. Vol. 13. No. 2. Pp. 305-317. (In Russ.) DOI: 10.22162/2619-0990-2020-48-2-305-31

Kuras L. V. 'Revolution in Kolchakiya' and background of the Mongolian Revolution in 1921. In: Levchenko V. M. et al. (eds.) Irkutsk Yearbook of History and Economics - 2017. Irkutsk: Baikal State University, 2017. Pp. 76-81. (In Russ.)

Kuras L. V. Buryat national autonomy 1917 in transnational history. In: Levchenko V. M. et al. (eds.) Irkutsk Yearbook of History and Economics - 2016. Irkutsk: Baikal State University, 2016. Pp. 84-92. (In Russ.)

Kuras L. V. Transnational History of the Mongolian World in a Revolutionary Upsurge: 1900s 1920s. Irkutsk: Ottisk, 2016. 252 p. (In Russ.)

Kuras L. V., Khishigt N., Tsybenov B. D. From 'Revolution in Kolchakia' to the Mongolian Revolution, 1921. In: Shalak A. V. et al. (eds.) Irkutsk Yearbook of History and Economics -
2020. Irkutsk: Baikal State University, 2020. Pp. 385-392. (In Russ.)

Kuras L. V., Tsybenov B. D. Otto Ivanovich Makstenek: year from life of the Soviet diplomat. The Bulletin of Irkutsk State University. Series 'History'. 2020. Vol. 32. Pp. 83-90. (In Russ.)

Melnikov I. D. Russian Civil War in Dzhidinsky District: 1918-1921. Collected Articles, Memoirs, and Biographic Materials. Ulan-Ude, 2011. 399 p. (In Russ.)

Roshchin S. K. Political History of Mongolia: 1921-1940. Moscow: Institute of Oriental Studies (RAS), 1999. 325 p. (In Russ.)

Sablin I. V. 'Wilson moment' in the Eastern Front: war, nationalism, and Buddhism in Siberia and Mongolia. In: Filippova T. A. (comp., ed.) Eastern Dimensions of World War I. Collected Scholarly Papers. Moscow: Institute of Oriental Studies (RAS), 2014. Pp. 135-136. (In Russ.)

Sablin I. V. Far Eastern Republic: From Idea to Abolition. Moscow: NLO, 2020. 260 p. (In Russ.)

Yaskina G. S. (ed.) History of Mongolia: 20 ${ }^{\text {th }}$ Century. Moscow: Institute of Oriental Studies (RAS), 2008. 448 p. (In Russ.) 